\title{
EFFECTS OF THE VIBRATIONS OF POWERED HAND TOOLS ON USERS: A CASE STUDY
}

\author{
Kolawole Adekunle ${ }^{1,2, *}$, Peter Ikubanni ${ }^{2}$, Adegoke Sanyaolu Adeboye ${ }^{1}$ \\ ${ }^{1}$ University of Ibadan, Ibadan, Nigeria \\ ${ }^{2}$ Landmark University, Omu-Aran, Nigeria
}

Powered hand tools reduce the time spent on tasks; however, they generate vibrations which may pose significant risk to operators' health. In this study, the impact of power hand tools on users was considered. Five basic power hand tools were identified and the impact of vibration was assessed on users. Digital vibration meter was used to measure the vibration produced on five operators while operating the identified power tools. Values obtained from each operator were imputed to the hand-arm vibration calculator to determine daily exposure limit and total exposure point for each of them. Results obtained indicate daily exposure limit of 4.08, 11.64, 21.06, 46.96 and 62.36 $\mathrm{m} / \mathrm{s}^{2}$; and average total exposure point of 261, 2242, 7107, 35436, and 63781; for hand milling machine, hand drilling machine, grinding machine, hand mower, and lawn mower respectively. Among the power tools examined, it is only the exposure vibration from hand milling machine that was within the recommended acceptable daily exposure limit of $5 \mathrm{~m} / \mathrm{s}^{2}$ and total exposure point of 400 . Measures were suggested to lessen the exposure time and vibration magnitude the operators are exposed to so as to reduce the probability of hand-arm vibration syndrome (HAVS) among the operators.

Key words: daily exposure limit, ergonomics, hand-arm vibration syndrome, powered hand tools

\section{INTRODUCTION}

The world is advancing and developing in science and technology, and the need to meet environmental demands is increasing very fast. Also, the competitive nature of today's market lead companies to the adoption of equipment, instruments, and tools that do not only ensure that customers demand are met but also ensure reduction in operation time, increase product quality and enhance mass production. Manual processes are being replaced by mechanical or automated processes and power driven manual tools. Job shop operations, construction, agricultural, environmental activities among others which usually require the use of manual hand tools may now be carried out with different types of powered tools that suit the work. Hand tool is any tool that is powered by the efforts of the users rather than engine. During the usage of the hand held tools, it has been observed that the characteristics of surface in contact with human hand have direct effect on the comfort and discomfort of the user [1]. Until the advent of powered tools, manual hand tools have been the principal source of assistance to man in carrying out different tasks. The place of hand tools in the workshop is important, however, to provide more professional results through jobs done in a much easier way and saving time, power tools become inevitable.

Macarthur [2] observed that "a powered tool is a tool that is actuated by an additional power source and mechanism other than the solely manual labour used with hand tools". Fredrick [3] observed that powered hand tools reduce tasks completion time, aid carrying out difficult task easily, and have obvious advantages of speed and are more efficient. In industrial work situations, the powered hand tools are the most common hand held industrial products found. The non-powered hand tools also have their usefulness in industries and daily life situations [4, 5]. The usage of powered hand tools by operators cause two major risk factors for hand/wrist injuries. Unnatural postures and repetitive forceful exertions are the major risks and can be reduced through ergonomic design / redesign of such products [6].

The hand-arm vibration (HAV) prevalence among workers that use powered hand tools or hand guided tools is reported to range from 6 to 100\%, with an average of approximately 50\% [7]. However, HAV depends on many interacting factors such as vibration exposure from prolonged and regular work with hand-guided power machinery or processes. These can have adverse effects on the hands and arms of users. Without effective controls, workers using such equipment may suffer various forms of damage, collectively known as hand-arm vibration syndrome (HAVS). South [8] defined vibration as a pendulum displacement about an equilibrium point of an object in which frequency, transportation domain and time period are the characteristics of it. Fredrick [3] defined hand-arm vibration (HAV) as vibration that occurs during the usage of vibrating hand-held power tools. The vibration is transmitted to the worker's hands and arms. This can happen when operating any hand-held power tools, hand-guided equipment, or by holding materials being processed by machines.

Previous researches on hand-arm vibration indicated that the level and duration of vibration of vibrating hand devices have effects on the users [9]. One of the effects 
is the Raynaud's phenomenon. Vibration may cause blood supply repression to the hands and fingers, which leads to numbness and tingling of the hands and fingers. Hand-arm vibration (HAV) is a potential risk for users that use hand-guided hardware or feed work by hand to a machine in that their hands and arms are exposed to elevated amounts of vibration. It may be noted that jobs that require continuous and regular vibrating tools and equipment are on the increase [10, 11]. Prolonged and regular exposure to extreme levels HAV can influence the user's wellbeing and particularly causing Hand-Arm Vibration Syndrome (HAVS) [12].

In view of the fact that prolonged and regular exposure to excessive vibration may lead to Hand-Arm vibration Syndrome [13]; this study considers vibration measurement and evaluation of five selected hand power tools and their effect on users due to vibration transmitted to the arms of operators during operations. The research was carried out on workers who make use of powered hand tools to perform some daily tasks in a public University in south western Nigeria by determining the total daily exposure value of workers and evaluate the impact of this vibration on them.

\section{MATERIALS AND METHOD}

Five workers operating five different power hand machines were selected for study. The methods adopted in this research include the personal inspection of power hand tools to be used in ascertaining being in good condition; observation of the worker posture when operating the machine; the usage of hand-arm vibrator and oral interviews with the operators.

\section{Inspection of tools and observation of worker posture}

Factors such as tool condition, state of tool maintenance, grip forces (how hard the operator grips the tool), and grip handle material and compatibility influence the effect of hand-arm vibration. An on-site inspection of tools is therefore required before measurement were taken. The tools were inspected to ensure they were in acceptable working conditions before measurements were commenced. Tool wears were also checked to ensure proper values are read on the vibration meter. Only skilled operators were considered for measurement.

\section{Measurement of transmitted vibration}

The ISO benchmarks for human vibration estimation necessitate that acceleration should be the parameter to be used to determine vibration levels. Digital VM-6360 vibration meter manufactured by $M$ and $A$ Instruments Inc. (Fig. 1) was used to measure the vibration released by the powered hand tools in accordance with ISO 2954 standard [14]. The meter was used to measure the instantaneous acceleration values at a particular time called peak value. Hand-arm vibration was evaluated using peak value and root means square (RMS) values of the acceleration produced by the rotating power tools to evaluate risk. The peak value was measured directly from the vibration meter but the RMS value was calculated through Eq. 1 as given by [15]:

Root mean square, $R M S=\frac{\text { Peak Value }}{\sqrt{2}}$

Measurements were taken thrice in this experiment to ensure accuracy and reliability and the average of the values obtained were used as the vibration value for each tool. Root mean square was used in hand-arm vibration calculator to determine the hand-arm exposure.

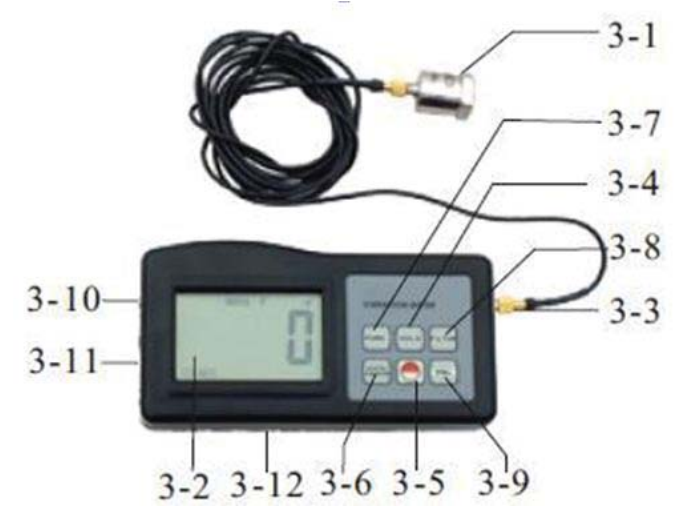

Figure 1: Vibration meters

Key: 3-1 Accelerometer; 3-2 Display; 3-3 Input Connector; 3-4 Hold key; 3-5 Power Key; 3-6 Metric/Imperial conversion key; 3-7 Function key; 3-8 Filter key; 3-9 Sound key; 3-10 Jack for the headphone; 3-11 Jack for RS232C interface and 3-12 Battery cover/compartment.

\section{Hand-arm calculator}

The Hand-Arm Vibration (HAV) Exposure calculator is an effective tool for the objective evaluation of HAV in the workplace. The pictureof the hard-arm vibration exposure calculator is shown in Fig. 2.

\section{Measurement of vibration magnitude}

The measure in-use method was utilised and vibration meter was used in determining acceleration. To obtain the vibration magnitude, the RMS value was calculated and inputted into the HAV calculator.

\section{Determining the exposure time}

The evaluated exposure time for each hand device was obtained by utilising a stop watch and estimation of a sample period of typical work. A stopwatch was utilised to determine the mean duration or the trigger time required to carrying out each task when the machine user was utilizing the device being evaluated.

The total exposure time was calculated by multiplying the trigger time by the number of repetition of task per day within 8 hour working shift as given in Eq. (2).

$$
E_{T}=T_{T} \times n_{T}
$$

where $E_{T}=$ Total daily exposure time; $T_{T}=$ trigger time and $n_{T}=$ number of times task was repeated in a day. 


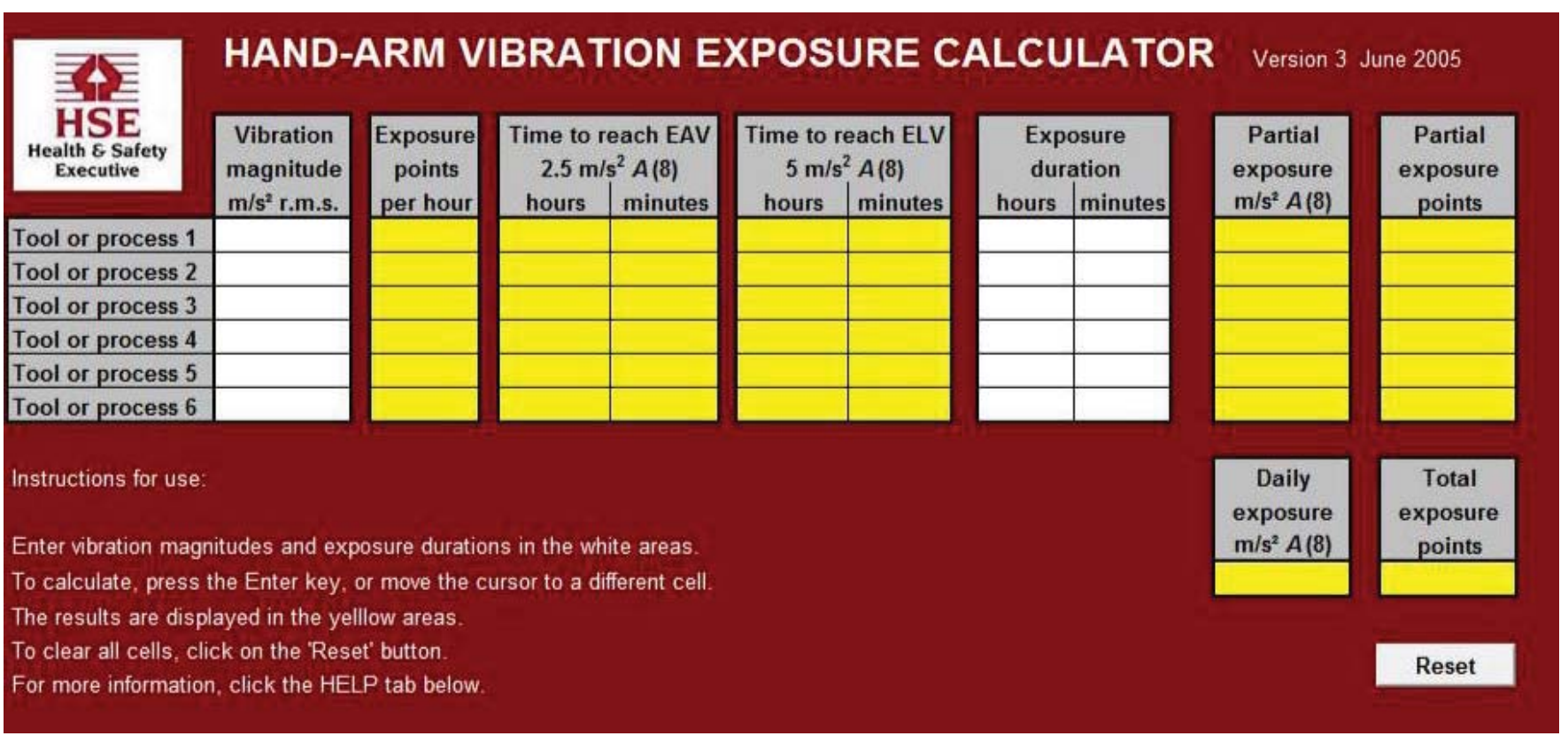

Figure 2: Hand-arm vibration calculator Interface [16]

Total daily vibration contact time or trigger time for each tool / process is inputted as exposure duration in the HAV calculator.

The extent of vibration effects can be calculated at the end of the experiment using Eq. 3. This is referred to as crest factor.

Crest factor $=\frac{\text { Peak value }}{\text { RMS value }}$

Based on the focus of this study, five most commonly used hand tools for carrying out various tasks within the campus of the University considered as case study were selected. The five identified tools are hand milling machine, hand drilling machine, hand mower, grinding machine and lawn mower. The operating conditions of the tools were examined to ensure the minimum acceptable working conditions in line with the manufacturers' standard were met before measurement of vibration. For complete evaluation of exposure to vibration, vibration acceleration measurement in meters per second squared $\left(\mathrm{m} / \mathrm{s}^{2}\right)$ was carried out. Vibration frequencies and duration (trigger time) of exposure were also determined.

\section{RESULTS AND DISCUSSION}

\section{Vibration readings}

Five operators of each tool randomly selected within the work environment had their transmitting vibrator level taken while tasks were being performed. Tables 1, 2, 3, 4 and 5 show the readings measured on hand milling machine, hand drilling machine, hand mower, grinding machine and lawn mower respectively.

\section{Determination of exposure duration}

The total exposure time was obtained by multiplying the number of times the task was repeated by the trigger time (i.e. actual exposure time). Table 6 shows the expo- sure time for each tool based on the number of repetition in 8 hours working shift for operator 1.

\section{Determination of acceptable exposure duration using hand-arm calculator}

To determine the acceptable exposure duration value for a daily 8hours working shift, time to reach exposure action value (EAV), exposure limit value (ELV) and total exposure point on each tool, the vibration magnitude for each operator (RMS value) were inputed into the HAV calculator. Figures 3 - 6 show the results obtained from the HAV calculator when operator 1 was operating the hand milling machine, hand drilling machine, lawn mower and grinding machine respectively. For limitation of space, figures for other operators could not be shown, but complete results for all the operators on the examined machines are summarised in Table 7.

\section{Hand milling machine}

The results in Table 7 indicate the exposure action value were reached at 3 minutes for operators 1, 2 and 3 but 2 minutes for operators 4 and 5 while exposure limit value were reached at 12 minutes for operator 1, 13 minutes for operators 2 and 4, 11 minutes for operator 3 and 9 minutes for operator 5 .

Exposure point of 225, 230, 271, 237, 343 for operators 1 to 5 and daily exposure of $4.0,3.8,4.1,3.9$ and $4.6 \mathrm{~m} / \mathrm{s}^{2}$ respectively were obtained when hand milling was being operated. These results indicate that the vibration the workers were exposed to while using this power hand tool is within the safe limit. It also indicates that operator 2 is least exposed and operator 5 is most exposed.

\section{Hand drilling machine}

The vibration evaluation of powered hand drilling ma- 
Table 1: Hand milling machine acceleration readings at $10 \mathrm{~Hz}-1 \mathrm{kHz}$

\begin{tabular}{|c|c|c|}
\hline Operator & $\begin{array}{c}\text { Average peak value } \\
\left(\mathrm{m} / \mathrm{s}^{2}\right)\end{array}$ & RMS $\left(\mathrm{m} / \mathrm{s}^{2}\right)$ \\
\hline 1 & 45.1 & 31.9 \\
\hline 2 & 42.8 & 30.3 \\
\hline 3 & 46.6 & 32.9 \\
\hline 4 & 43.6 & 30.8 \\
\hline 5 & 52.4 & 37 \\
\hline $\begin{array}{c}\text { Average Operator } \\
\text { Value }\end{array}$ & 46.1 & 32.6 \\
\hline
\end{tabular}

Table 2: Hand drilling machine acceleration readings at $10 \mathrm{~Hz}-1 \mathrm{kHz}$

\begin{tabular}{|c|c|c|}
\hline Operator & $\begin{array}{c}\text { Average peak value } \\
\left(\mathrm{m} / \mathrm{s}^{2}\right)\end{array}$ & RMS $\left(\mathrm{m} / \mathrm{s}^{2}\right)$ \\
\hline 1 & 99.1 & 70.1 \\
\hline 2 & 86.1 & 60.9 \\
\hline 3 & 109.8 & 77.6 \\
\hline 4 & 117.8 & 83.2 \\
\hline 5 & 114.6 & 81 \\
\hline $\begin{array}{c}\text { Average Operator } \\
\text { Value }\end{array}$ & 105.5 & 74.6 \\
\hline
\end{tabular}

Table 3: Grinding machine acceleration readings at $10 \mathrm{~Hz}-1 \mathrm{kHz}$

\begin{tabular}{|c|c|c|}
\hline Operator & $\begin{array}{c}\text { Average peak value } \\
\left(\mathrm{m} / \mathrm{s}^{2}\right)\end{array}$ & RMS $\left(\mathrm{m} / \mathrm{s}^{2}\right)$ \\
\hline 1 & 145.5 & 102.9 \\
\hline 2 & 145.2 & 102.7 \\
\hline 3 & 138.5 & 97.91 \\
\hline 4 & 142.6 & 100.8 \\
\hline 5 & 133.4 & 94.3 \\
\hline $\begin{array}{c}\text { Average Operator } \\
\text { Value }\end{array}$ & 141.1 & 99.7 \\
\hline
\end{tabular}

chine from the HAV calculator reveals the exposure action limit will be reached in 1 minute for operators 1 and 2; and zero for other operators. It also indicates 2 minutes as time to reach exposure limit value for all operators except operator 2 with 3 minutes. The total exposure point and daily exposure value for all operators indicate that the safe points have been surpassed and users of the tool are at risk of having HAVS. Controls should be executed promptly to decrease the exposure to vibration magnitude.

\section{Grinding machine}

Results indicate 1 minute as time taken to reach exposure limit value and zero minutes to reach exposure
Table 4: Powered hand mower acceleration readings at $10 \mathrm{~Hz}-1 \mathrm{kHz}$

\begin{tabular}{|c|c|c|}
\hline Operator & $\begin{array}{c}\text { Average peak value } \\
\left(\mathrm{m} / \mathrm{s}^{2}\right)\end{array}$ & RMS $\left(\mathrm{m} / \mathrm{s}^{2}\right)$ \\
\hline 1 & 145.5 & 102.9 \\
\hline 2 & 145.2 & 102.7 \\
\hline 3 & 138.5 & 97.91 \\
\hline 4 & 142.6 & 100.8 \\
\hline 5 & 133.4 & 94.3 \\
\hline $\begin{array}{c}\text { Average Operator } \\
\text { Value }\end{array}$ & 141.1 & 99.7 \\
\hline
\end{tabular}

Table 5: Lawn mower acceleration readings at $10 \mathrm{~Hz}-1 \mathrm{kHz}$

\begin{tabular}{|c|c|c|}
\hline Operator & $\begin{array}{c}\text { Average peak value } \\
\left(\mathrm{m} / \mathrm{s}^{2}\right)\end{array}$ & RMS $\left(\mathrm{m} / \mathrm{s}^{2}\right)$ \\
\hline 1 & 152.8 & 108 \\
\hline 2 & 211.4 & 149.5 \\
\hline 3 & 223.3 & 157.9 \\
\hline 4 & 220.7 & 156 \\
\hline 5 & 209.5 & 148.1 \\
\hline $\begin{array}{c}\text { Average Operator } \\
\text { Value }\end{array}$ & 203.54 & 143.9 \\
\hline
\end{tabular}

Table 6: Exposure duration for operator 1 on all the machines

\begin{tabular}{|c|c|c|c|}
\hline Tool & $\begin{array}{c}\text { Observed } \\
\text { trigger } \\
\text { time (min) }\end{array}$ & $\begin{array}{c}\text { Number of } \\
\text { repetition } \\
\text { within 8 } \\
\text { hours shift }\end{array}$ & $\begin{array}{c}\text { Total } \\
\text { exposure } \\
\text { time (min) }\end{array}$ \\
\hline $\begin{array}{c}\text { Hand milling } \\
\text { machine }\end{array}$ & 1.5 & 5 & 7.5 \\
\hline $\begin{array}{c}\text { Hand drilling } \\
\text { machine }\end{array}$ & 2.5 & 4 & 10 \\
\hline $\begin{array}{c}\text { Grinding } \\
\text { machine }\end{array}$ & 2 & 11 & 22 \\
\hline Hand mower & 5 & 14 & 70 \\
\hline Lawn mower & 3 & 30 & 90 \\
\hline
\end{tabular}

action value. This means high significant risk of HAVS in a short time. The high total exposure point and high daily exposure with least value on operator 5 implies that daily exposure to the tool should be avoided. It is recommended that if possible other alternatives of doing the job should be employed.

\section{Hand mower}

Results indicate 1 minute as time taken to reach exposure limit value, zero minute for all operators to reach exposure action value, daily exposure of 46.0 to 
$47.4 \mathrm{~m} / \mathrm{s}^{2}$, and 33908 to 37962 total exposure point indicate that the tool generally produce high vibration. The users are highly exposed to hand arm vibration syndrome (HAVS) in a very short time. It further means the tool should be avoided if possible or other alternative(s) of doing the job should be emplored.

\section{Lawn mower}

With high daily exposure and very high total exposure point, this power tool poses very high significant risk of HAVS in a very short time to all operators. The tool should be avoided or reduction on the usage should be encouraged. Possible alternatives of doing the job should be employed.

\section{Vibration effects}

According to [5], one of the major causes of occupational diseases and injuries at work is vibration. It is probably one of the reasons behind subjective discomfort at work. This study has considered the vibration effects of five powered hand tools used by the operators, and four out of the five powered hand tools emit vibrations that are higher than the allowable limit. Vibration effect over a long time on the operator will pose insensitivity to the vibrated hand area due to repetitive forceful efforts required in operating the machine. The repetitiveness and the high velocities of the powered hand tools are likely to cause the high prevalence of discomfort in the hands of the operators [17].

\section{Possible control measures}

Basically, there are two suggested ways by which HAVS risk exposure can be reduced or eliminated. Lowering the vibration value and decreasing exposure time could reduce the risk posed on the operators. Vibration value can be reduced by using modern tools or modern machining method as these tools emit very low vibration. Exposure time on the other hand can be reduced by changing the machining processing to a more efficient process or by introducing job rotation. By introducing job rotation, the daily exposure value for each operator can be reduced. Moreover, in accordance with the study of [11], anti-vibration gloves should be provided for the operators. These anti vibration gloves are used to reduce the vibration that can be transferred to the hands $[18,19]$. Anti vibration gloves should be utilised as an alternative means to lessen hand transmitted vibration exposure.

More so, occupational safety and health measures should be put in place to reduce the number of occupational injuries and diseases, and work-related illnesses. Therefore, to efficiently manage the occupational safety and health system, a systematic and process approach should be put in place to define, monitor and adjust the performance indicators [20].

\section{CONCLUSION}

Usage of power hand tools may expose workers to vibrations that may be beyond what they can cope with. This may lead to permanent negative effect especially when contacted on regular basis. In this study, the impact of the vibrations that five power hand tools that are used for environmental and workshop activities in a public University in Nigeria on users were examined. Among the five tools investigated, only one appeared safe while the remaining four tools pose threat to the well-being of the workers as they transmit very high amount of vibration that are beyound acceptable level thereby subjecting the workers to high risk of acquiring HAVS disease with time. In order to prevent this, it is suggested that the exposure time should be reduced by job rotation and provision of anti-vibration gloves for the workers.

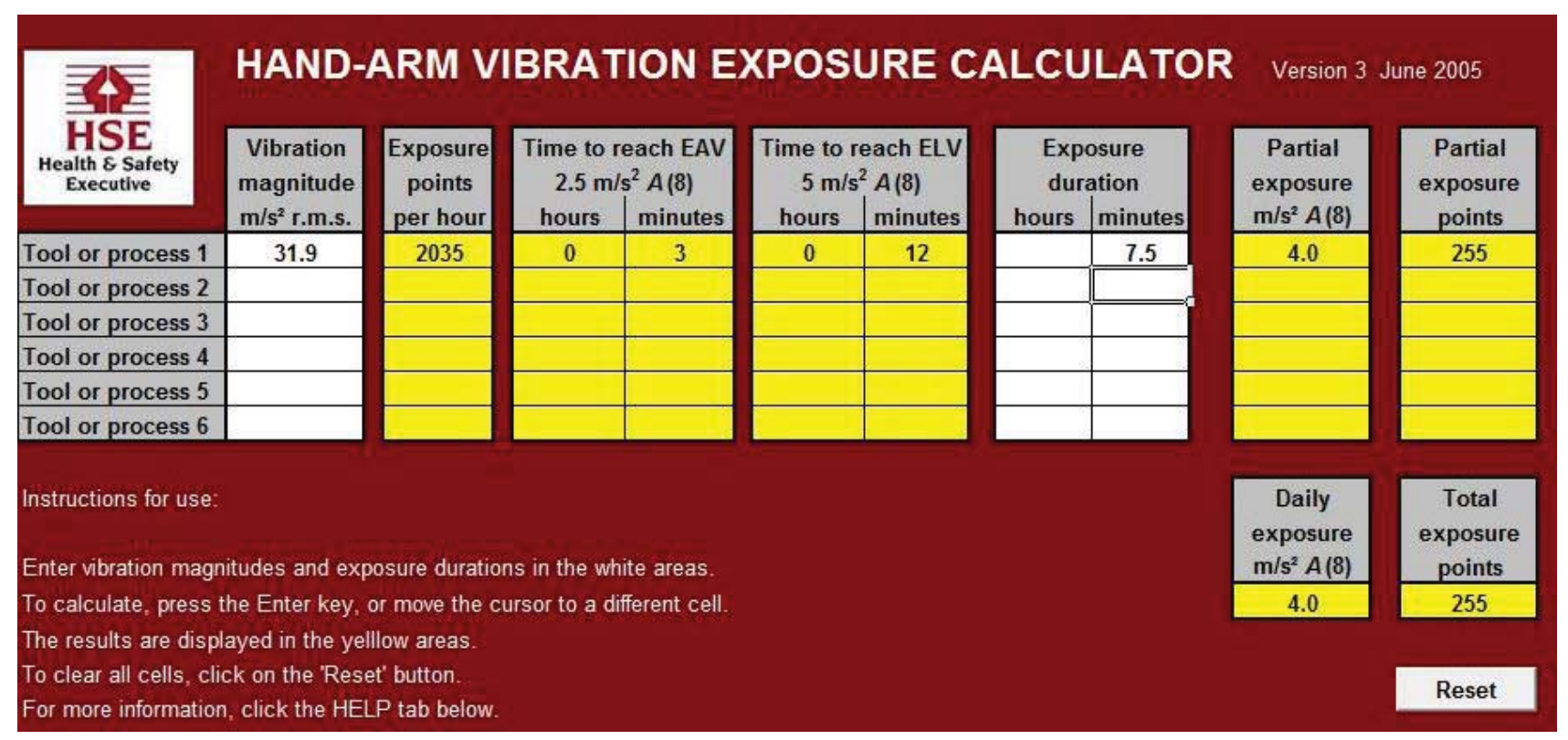

Figure 3: Hand milling machine HAV result for operator 1 


\begin{tabular}{|c|c|c|c|c|c|c|c|c|c|c|}
\hline$\underset{\substack{\text { Health \& Safety } \\
\text { Executive }}}{\overline{\text { HSEE }}}$ & $\begin{array}{l}\text { Vibration } \\
\text { magnitude } \\
\mathrm{m} / \mathrm{s}^{2} \text { r.m.s. }\end{array}$ & $\begin{array}{c}\text { Exposure } \\
\text { points } \\
\text { per hour }\end{array}$ & $\begin{array}{r}\text { Time to } \\
2.5 \mathrm{~m} \\
\text { hours }\end{array}$ & $\begin{array}{l}\text { each EAV } \\
A(8) \\
\text { minutes }\end{array}$ & $\begin{array}{r}\text { Time to } \\
5 \mathrm{~m} / \\
\text { hours }\end{array}$ & $\begin{array}{l}\text { each ELV } \\
A(8) \\
\text { minutes }\end{array}$ & $\begin{array}{l}\text { Expc } \\
\text { dure } \\
\text { hours }\end{array}$ & $\begin{array}{l}\text { sure } \\
\text { ation } \\
\text { minutes }\end{array}$ & $\begin{array}{c}\text { Partial } \\
\text { exposure } \\
\mathrm{m} / \mathrm{s}^{2} A(8)\end{array}$ & $\begin{array}{c}\text { Partial } \\
\text { exposure } \\
\text { points }\end{array}$ \\
\hline Tool or process 1 & 70.1 & 9828 & 0 & 1 & 0 & 2 & & 12 & 11.1 & 1967 \\
\hline \multicolumn{11}{|l|}{ Tool or process 2} \\
\hline \multicolumn{11}{|l|}{ Tool or process 3} \\
\hline \multicolumn{11}{|l|}{ Tool or process 4} \\
\hline \multicolumn{11}{|l|}{ Tool or process 5} \\
\hline \multicolumn{11}{|l|}{ Tool or process 6} \\
\hline \multicolumn{9}{|l|}{ Instructions for use: } & $\begin{array}{c}\text { Daily } \\
\text { exposure } \\
\mathrm{m} / \mathrm{s}^{2} A(8) \\
\end{array}$ & $\begin{array}{c}\text { Total } \\
\text { exposure } \\
\text { points } \\
\end{array}$ \\
\hline \multicolumn{9}{|c|}{ To calculate, press the Enter key, or move the cursor to a different cell. } & 11.1 & 1967 \\
\hline \multicolumn{11}{|c|}{ The results are displayed in the yelllow areas. } \\
\hline \multicolumn{10}{|c|}{ To clear all cells, click on the 'Reset' button. } & Reset \\
\hline
\end{tabular}

Figure 4: Hand drilling machine HAV result for operator 1

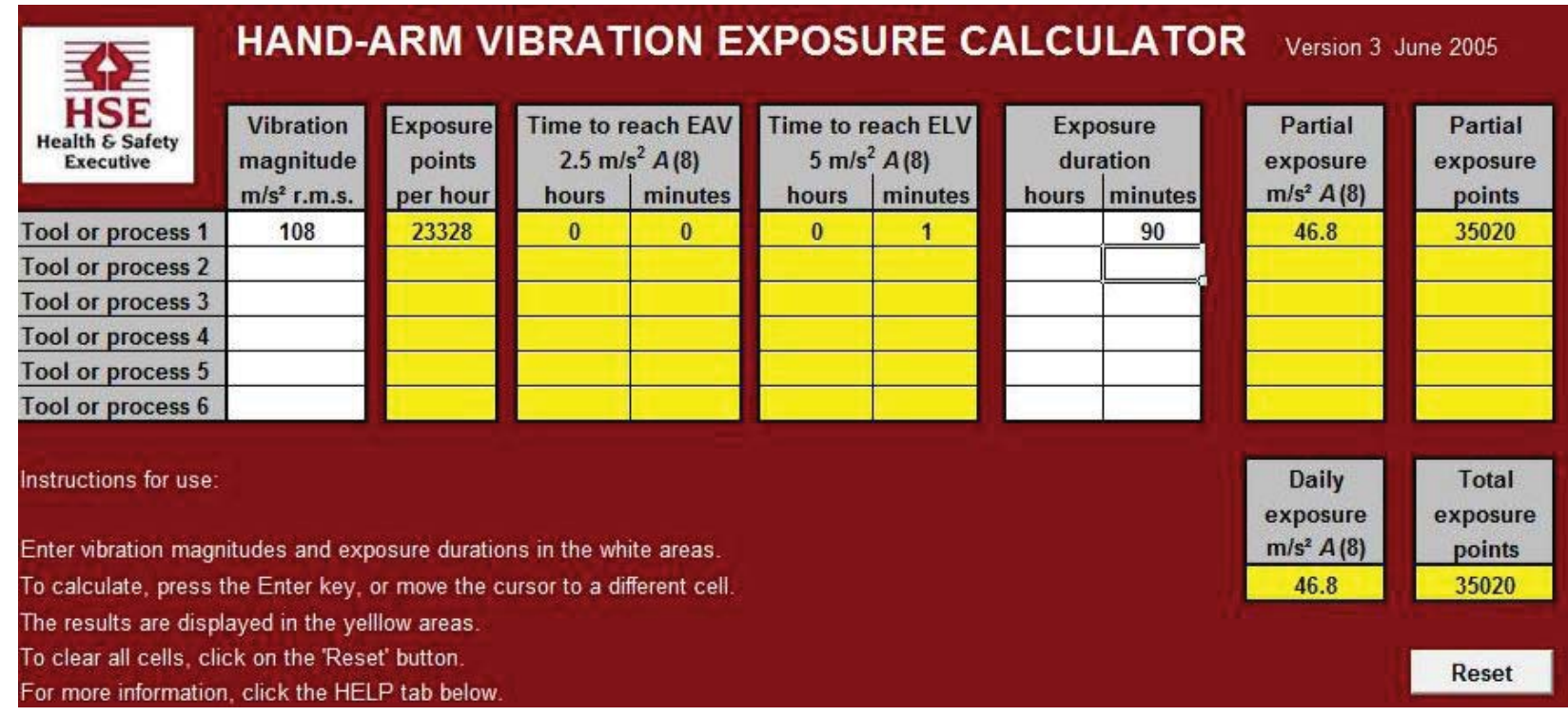

Figure 5: Lawn mower machine HAV result for operator 1

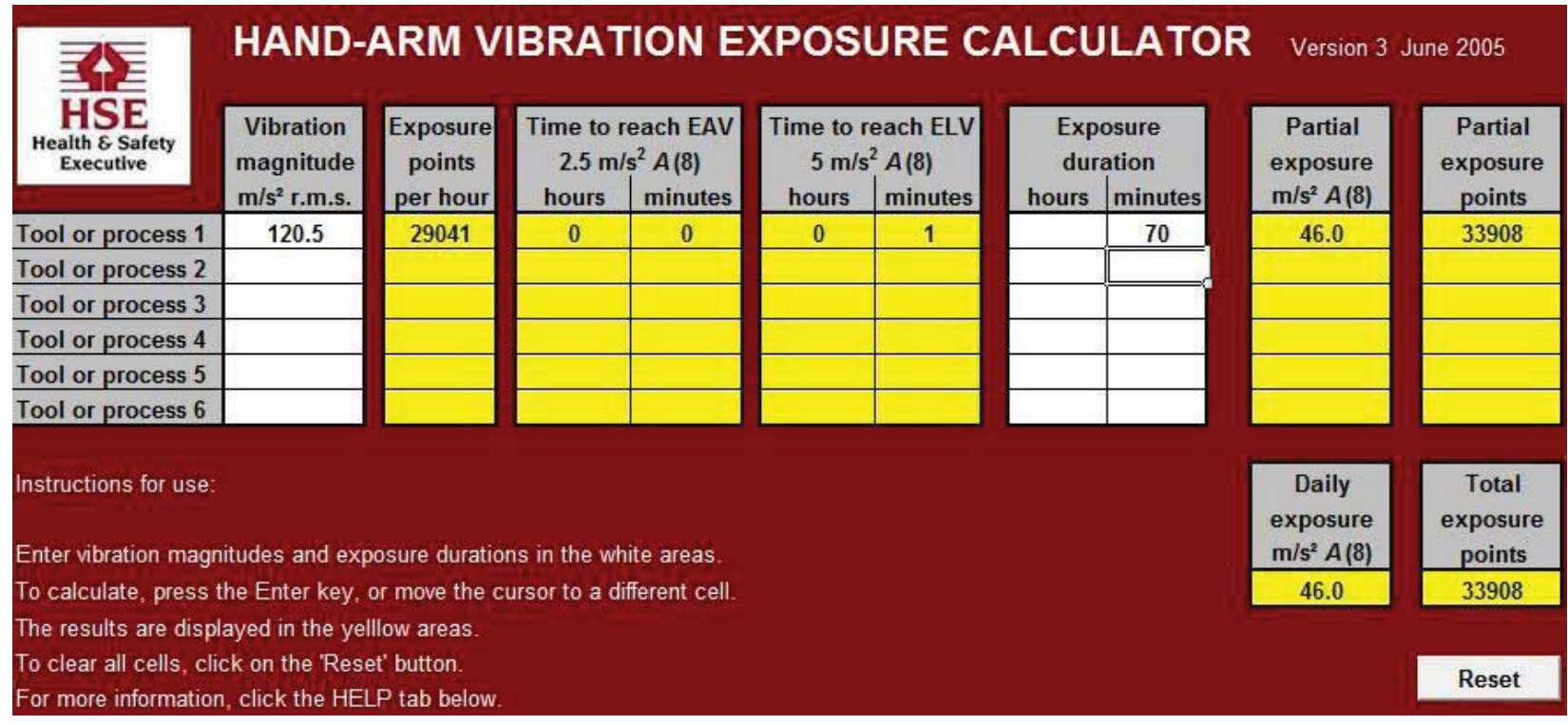

Figure 6: Grinding machine HAV result for operator 1 
Table 7: Results from HAV calculator for the different tools

\begin{tabular}{|c|c|c|c|c|c|c|}
\hline Hand Tool & & $\begin{array}{c}\text { Exposure } \\
\text { points per } \\
\text { hour }\end{array}$ & $\begin{array}{c}\text { Time to reach } \\
\text { exposure } \\
\text { (min) }\end{array}$ & $\begin{array}{l}\text { Time to reach } \\
\text { exposure limit } \\
\text { value (min) }\end{array}$ & $\begin{array}{l}\text { Daily exposure } \\
\text { limit }\left(\mathrm{m} / \mathrm{s}^{2}\right)\end{array}$ & $\begin{array}{c}\text { Total exposure } \\
\text { point }\end{array}$ \\
\hline \multirow{5}{*}{$\begin{array}{l}\text { Hand milling } \\
\text { machine }\end{array}$} & Operator 1 & 2035 & 3 & 12 & 4.0 & 225 \\
\hline & Operator 2 & 1836 & 3 & 13 & 3.8 & 230 \\
\hline & Operator 3 & 2165 & 3 & 11 & 4.1 & 271 \\
\hline & Operator 4 & 1897 & 2 & 13 & 3.9 & 237 \\
\hline & Operator 5 & 2738 & 2 & 9 & 4.6 & 343 \\
\hline \multirow{5}{*}{$\begin{array}{l}\text { Hand drilling } \\
\text { machine }\end{array}$} & Operator 1 & 9828 & 1 & 2 & 11.1 & 1967 \\
\hline & Operator 2 & 7418 & 1 & 3 & 9.6 & 1485 \\
\hline & Operator 3 & 12044 & 0 & 2 & 12.3 & 2411 \\
\hline & Operator 4 & 13844 & 0 & 2 & 13.2 & 2721 \\
\hline & Operator 5 & 13122 & 0 & 2 & 12.0 & 2627 \\
\hline \multirow{5}{*}{$\begin{array}{l}\text { Grinding } \\
\text { machine }\end{array}$} & Operator 1 & 21177 & 0 & 1 & 21.7 & 7559 \\
\hline & Operator 2 & 21095 & 0 & 1 & 21.7 & 7530 \\
\hline & Operator 3 & 19173 & 0 & 1 & 20.7 & 6844 \\
\hline & Operator 4 & 20321 & 0 & 1 & 21.3 & 7254 \\
\hline & Operator 5 & 1775 & 0 & 1 & 19.9 & 6348 \\
\hline \multirow{5}{*}{ Hand Mower } & Operator 1 & 29041 & 0 & 1 & 46.0 & 33908 \\
\hline & Operator 2 & 29719 & 0 & 1 & 46.4 & 34473 \\
\hline & Operator 3 & 32513 & 0 & 1 & 48.3 & 37962 \\
\hline & Operator 4 & 30802 & 0 & 1 & 47.4 & 35964 \\
\hline & Operator 5 & 29866 & 0 & 1 & 46.7 & 34872 \\
\hline \multirow{5}{*}{ Lawn Mower } & Operator 1 & 23328 & 0 & 1 & 46.8 & 38020 \\
\hline & Operator 2 & 44701 & 0 & 1 & 64.8 & 67105 \\
\hline & Operator 3 & 49865 & 0 & 0 & 68.4 & 74858 \\
\hline & Operator 4 & 48672 & 0 & 0 & 67.6 & 73067 \\
\hline & Operator 5 & 43807 & 0 & 1 & 64.2 & 65854 \\
\hline
\end{tabular}

\section{REFERENCES}

1. Kuijt-Evers, L.F.M., Boscha, T., Huysmansc, M. A., De Looze, M. P., Vink, P.(2007). Association between between objective and subjective measurements of comfort and discomfort in hand tools.Applied Ergonomics,vol. 38, 643-654.

2. Macarthur, B. (2015).Apparatus including powered tool configured to fasten fastener to assembly United States, Honda Motor Co., Ltd. Tokyo, Japan, Patent No: 9108307, available at: http://www.freepatentsonline.com/9108307.html (accessed: 12th August 2018).
3. Fredrick, H. Advantages and disadvantages of power hand tools.available at: http://www.ehow. com/info_8566574_advantages-disadvantages-hand-power-tools.html/(Accessed:17-Nov- 2018)

4. Kong, Y.K., Lowe, B.D., Lee, S.J.,Krieg, E.F. (2008). Evaluation of handle shapes for screw driving. Applied Ergononomics, vol. 39, 191-198.

5. Bisht, D.S.,Khan, M.R. (2013). Ergonomic Assessment Methods for the Evaluation of hand held industrial products: A review.In: Proceedings of the World Congress on Engineering, July 3 -5, 2013, London, UK.

6. Li, K.W. (2002). Ergonomic design and evaluation of wire-tying hand tools. International Journal of Industrial Ergonomics, vol. 30, 149-161. 
7. National Occupational Safety and Health (NIOSH) (1989). Occupational Exposure to Hand-Arm Vibration: Criteria for a Recommended Standard. [DHHS (NIOSH) Publication No. 89-106.] Cincinnati, OH: US Department of Health and Human Services, Public Health Service, Centers for Disease Control and Prevention, National Institute for Occupational Safety and Health, 1-127.

8. South, T. (2004).Managing Noise and Vibration at Work, Butterworth Heinemann Books, Oxford, UK, 8085.

9. Das, B. (2007). Assessment of the Ergonomics Quality of Hand-Held Tools and Computer Input Devices. Ergonomic, Human Factors and Safety, vol. 1, 23-29.

10. Forouharmajd, F., Nassiri, P. (2011). The evaluation of hand arm vibration levels in hand held pneumatic tools (Rock Drill) by pneurop Cagi test code.Journal of Low Frequeny Noise Vibration and Active Control, vol. 30, no. 4, 329333.

11. Forouharmajd, F., Azmoon, H., Akbari, J. Soury, S. (2016).Evaluating the transmitted vibration to operator's hands hand and effect of protective gloves in real condition, based on International Standard Organization 5349 standard. International Journal of Environmental Health Engineering. vol. 4, no. 4, 1-5.

12. Boyle, J.C., Smith, N.J.,Burke, F.D. (1988).Vibration white finger. Journal of Hand Surgery.vol. 13, 171 176.

13. Dong, R.G., Sinsel, E.W., Welcome, D.E., Warren, C., Xu, X.S., McDowell, T.W., Wu, J.Z. (2015). Review and evaluation of hand-arm coordinate systems for measuring vibration exposure, biodynamic responses, and hand forces. Safety and Health Work, vol. 6, no. 3, 159-173.
14. ISO 2954 (2012). Mechanical vibration of rotating and reciprocating machinery - Requirements for instruments for measuring vibration severity.

15. Griffin, M. J. (2012). Hand book of human vibration, Elsevier Academic Press, London, UK.

16. HSE Books (2005). Control the risks from hand-arm vibration - Advice for employers on the Control of Vibration at Work Regulations, available at: www.hse. gov.uk/pubns/indg175.pdf, (accessed: 20November 2018].

17. Arvidsson, I., Akesson, I. and Hansson, G. A. (2003). Wrist movements among females in a repetitive, non-forceful work. Applied Ergonomics, vol. 34, 309-316.

18. Rens, G., Dubrulle, P., Malchaire, J. (1987).Efficiency of conventional gloves against vibration. The Annals of Occupational Hygiene, vol. 31, no. 2, 249 254.

19. Reynolds, D., Jetzer, T. (1998). Use of air bladder technology to solve hand tool vibration problems. in: Proceedings of the Eighth International Conference on Hand Arm Vibration, Umea, Sweden.

20. Vranjes, B., \& Todic, M. [2019]. A model of analysis of the occupational safety and health system in the production system. Journal of Applied Engineering Science, 17(3), $264-272$. 